\title{
3つの異なる座位保持課題が腰椎分節の 角度変化に及ほすす影響
}

\author{
Lumbar Intervertebral Angles and Back Muscle Activities \\ of Three Different Types of Sitting
}

\author{
野田 敏生 ${ }^{1)} \quad$ 齊藤 大介 $^{2)}$ 古川 公宣 ${ }^{3)}$ \\ TOSHIKI NODA, RPT, MS ${ }^{1)}$, DAISUKE SAITO, RPT ${ }^{2)}$, KIMINOBU FURUKAWA, RPT, $\mathrm{PhD}^{3)}$ \\ ${ }^{1)}$ Department of Rehabilitation, Toyohashi Orthopedic Takaoka Clinic: 106-1 Nakagou, Ushikawa-cho, Toyohashi-shi, Aichi \\ 440-0016, Japan TEL +81 5-3274-8881 E-mail: t.noda@seiyukai.or.jp \\ ${ }^{2)}$ Department of Rehabilitation, Toyohashi Orthopedic Surgery Esaki Hospital \\ 3) Division of Physical Therapy, School of Care and Rehabilitation, Seijoh University
}

Rigakuryoho Kagaku 32(5): 645-649, 2017. Submitted Apr. 7, 2017. Accepted May 25, 2017.

\begin{abstract}
Purpose] This study aimed to define the region where load is concentrated and to observe the temporal changes in the intervertebral angles of the lumbar spine of three types of sitting: lumbopelvic upright sitting, slump sitting, and thoracic upright sitting. [Subjects and Methods] The subjects were 16 healthy adult men who maintained each of the three sitting postures for 20 min with a $20 \%$ body weight load regulated by belts suspending the shoulders bilaterally. Intervertebral angle changes from L2 to S1 were measured using a three-dimensional ultrasonic motion analysis system. [Results] Significant kyphotic changes during lumbopelvic upright sitting were sequentially observed after 4, 5, 7 and 11 min from the upper segment downwards. In thoracic upright and slump sitting, no significant changes in intervertebral angles were observed. [Conclusion] The results of this study suggest that intervertebral angles of the lumbar spine during lumbopelvic and thoracic upright sitting converge with those of slump sitting. It is speculated that the mechanical demands of supporting the spinal structure are transferred from the spinal musculature to the passive tissues, which undergo elongation stress during slump sitting. Hence, sedentary workers should change their posture frequently.
\end{abstract}

Key words: Lumbopelvic upright sitting, lumbar intervertebral angle changes, passive tissues of the spine

要旨：〔目的〕本研究の目的は, Lumbo-pelvic upright sitting, Slump sitting, Thoracic upright sitting を保持する間の 腰椎分節角度の経時的変化を観察し，その特徵について検討することである。〔対象と方法〕健常成人男性 16 人を対 象とした，体重の $20 \%$ の重錘を両側肩関節に懸垂した，3 種類の座位姿勢を 20 分間保持することで腰椎への経時的 な負荷を短時間で再現した。〔結果〕Lumbo-pelvic upright sittingは, 下位腰椎から順に屈曲方向に有意な角度増加を 示したが，その他の座位姿勢は，有意な変化を示さなかった。〔結語〕Lumbo-pelvic upright sitting を長時間保持する ことは困難であり, 脊柱を支持する力源の割合が, 筋から脊柱の受動性組織に徐々に移行していることが明らかとなっ た.

キーワード : Lumbo-pelvic upright sitting, 腰椎分節の角度変化, 脊柱の受動性組織

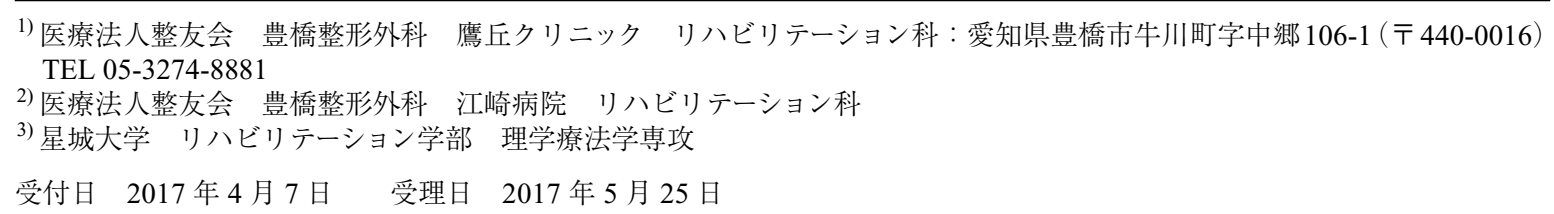




\section{I.はじめに}

慢性腰痛症は,「3 3 月以上持続する腰痛」と定義さ れている ${ }^{1)}$. Katzら 2)は, これが全米に扔ける就労欠 如要因の第 1 位であり, その社会的損失は 1,000 億ドル から 2,000 億ドルと試算でき, 大きな社会問題となって いると報告した，腰痛症は $84 \%$ の人が一生のうちに一 度は経験すると言われており3)，我が国に扔いても，男 性では有訴率が最も多く, 女性では肩こりに次いで 2 番 目に多い愁訴であった ${ }^{4)}$ ，今や腰痛症は，患者の社会参 加を妨げることによる経済損失も莫大であり, 今後, 医 療費の高騰とともに就労困難による生産性の低下など, 社会経済に与える損失が増大していくことが予想され る5).

また, 本疾患は職業性疾病の 6 割を占め, 長時間のデ スクワークを行う事務職や長距離運転を行う運輸職での 有症率が高いとも言われている ${ }^{6}$. 作業中の不適切な姿 勢や定期的に姿勢を変えられない作業は症状を増悪させ るとの報告もあり 7), 労働者の健康確保にとっても予防 対策が大きな課題となっている，そのため, 厚生労働省 は職業性疾病の腰痛予防対策の必要性を訴えて扮り 8 , 現代社会に扔いてその治療法や予防法を確立することは 重要な課題である.

疫学研究より, 長時間の座位姿勢を強いられる職業は, 腰痛やヘルニアの発生率を高めると言われており 9-11), McGill ら ${ }^{12)}$ は, 腰椎を前方に最大屈曲させた座位姿勢 を長時間保つことにより, 腰部受動性組織が徐々に伸張 され菲薄化する (クリープ現象) ことで強度低下を起こ し，脊柱の安定性が損なわれたと報告している。

また，座位の相違によって起こる体幹の筋活動と脊柱 の可動域の変化について, O'Sullivan ら 13) は, 腰椎の 生理的前弯を保つ Lumbo-pelvic upright sitting, 肩甲骨 間を近づけて胸腰部を努力性に伸展させるThoracic upright sitting, 胸腰部を脱力して骨盤を後傾する Slump sittingの 3 つに分類して解析している。 この報告では, Lumbo-pelvic upright sitting は, 他に比べて腰椎の前弯 角度が有意に大きく, 腰部深層筋筋活動が有意に高い。 Thoracic upright sitting は, 腰椎の前弯角度が Lumbopelvic upright sitting より有意に小さく, 表層筋が有意 に高い. Slump sitting は, 脊柱起立筋に屈曲弛緩現象 (Flexion Relaxation Phenomenon：以下, FRP) が発生し 腰椎を生理的前弯に保つ力源を非収縮性の受動性組織に 依存しているとなっており, 姿勢の違いによって, 腰椎 の構造体や筋に加わる負担度が異なることが示された。

以上の報告より, 腰椎の生理的前弯を保つ Lumbopelvic upright sittingは, 梁層筋を有意に働かせ, 脊柱 の勒帯軟部組織, 椎間板への急担が少なく, 推奨される 座位である。一方，脊柱を最大屈曲した Slump sitting は， 腰部受動性組織の負担が大きく推奨されない姿勢である

\begin{tabular}{ll} 
表 1 対象者の特性 \\
\hline 人数 & 16 人 \\
年齢 & $30.5 \pm 6.8$ 歳 \\
身長 & $171.1 \pm 5.8 \mathrm{~cm}$ \\
体重 & $65.1 \pm 8.8 \mathrm{~kg}$ \\
利き手 & 右: 15 人, 左 : 1 人 \\
利き足 & 右 : 15 人, 左 $: 1$ 人 \\
\hline
\end{tabular}

と言われている，長時間の座位保持中に腰椎の屈曲角度 を観察した先行研究は，そのほとんどが腰椎全体を測定 して打り，分節に打ける角度変化を調査したものはな い，そのため，座位を長時間保持している間の経時的な 腰椎分節の角度変化は，現在のところ明らかにされてい ない.

そこで今回は, Lumbo-pelvic upright sitting, Slump sitting 挹よび努力性に腰椎を伸展位にするThoracic upright sitting を保持する間の腰椎分節の経時的な角度 変化を観察し，その特徵について検討した，長時間座位 保持をしている間，分節に扔ける角度変化を経時的に調 查する臨床的意義は, 腰部組織の強度が低下する関節の 位置を同定でき，慢性腰痛症を予防するための適切な作 業姿勢, 作業時間などの指導を行う一助になると考えて いる.

\section{II. 対象と方法}

1. 対象

対象は健常男性 16 人とした，それらを表 1 に示す。 包含基準は， 1 年以内に強い腰部痛を経験していない, かつ腰部に障害を残遺する疾患および外傷の既往がない 者とした。

2. 方法

大腿骨をベッドに対して平行, 股関節内外旋 $0^{\circ}$, 膝 関節屈曲 $90^{\circ}$ とし, 下腿は下垂して足底を床から離すよ うに治療用ベッドに着座した。そとて，長時間の座位保 持で生じる腰椎への経時的な負荷を短時間で再現するた めに, Kanlayanaphotporn ら 14) が行った重量負荷にて 再現する方法を改変し，体重の $20 \%$ の重錘を両側肩関 節に掛けた懸垂ベルトに装着した（図 1).

この状態で，図 2 に示す Lumbo-pelvic upright sitting, Slump sitting, Thoracic upright sitting 20 分間保持し た。課題遂行中に, 被験者の頭頸部の動きが腰椎の分節 角度や筋活動に影響することを避けるため, 目線の高さ を一定にして前方の壁を見つめるように指示した．被験 者には，測定前に 3 つの座位姿勢の保持が再現できるよ 
a

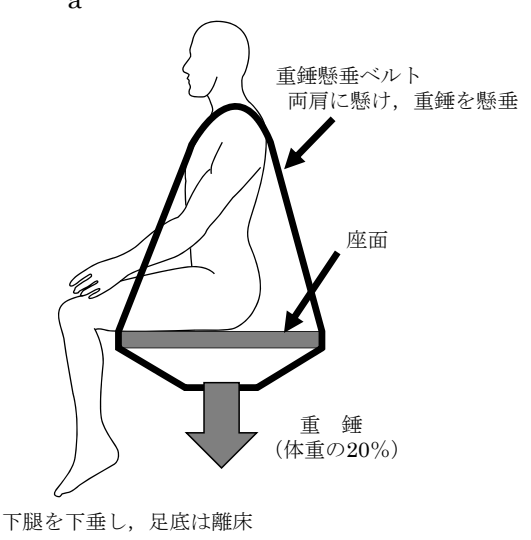

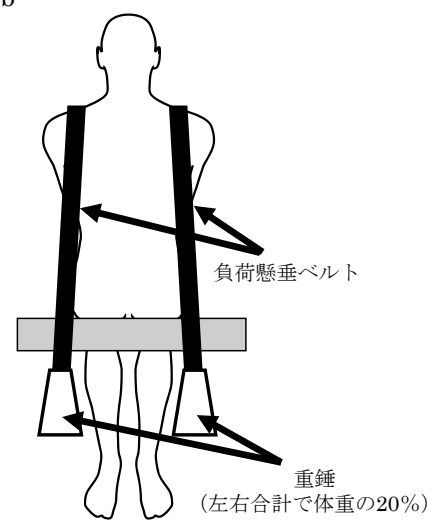

図1 長時間座位保持再現のための実験設定

$\mathrm{a}$ : 側面, b : 後面.

a

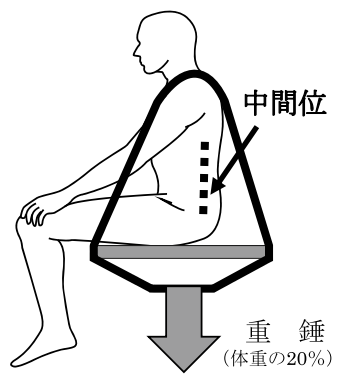

b

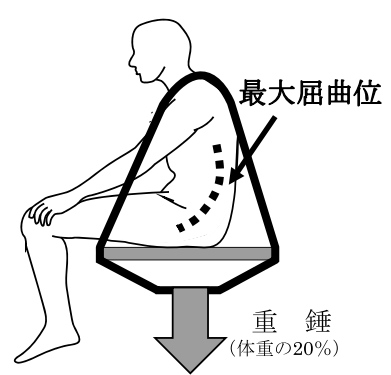

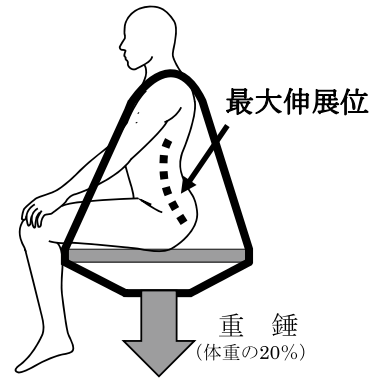

図23種類の座位姿勢

$\mathrm{a}$ : Lumbo-pelvic upright sitting, b : Slump sitting, $\mathrm{c}$ : Thoracic upright sitting.

うに, Lumbo-pelvic upright sitting は立位姿勢時の腰の 反りを座位姿勢でも保つように, Slump sitting は身体を 脱力し，骨盤を後ろに傾けて背中が丸くなるように， Thoracic upright sittingは肩甲骨間を近づけ, 背中を最 大に反るようにと口頭指示を行った，加えて，開始時の 姿勢が確実に遂行できるよう，十分な練習時間を確保し， 椎間板や受動性組織の十分な復元期間を設けるために, 各課題の試行には 7 日間以上の期間を設けた。

腰椎分節間の角度変化は, 超音波式 3 次元動作解析シ ステム（WINSPINE：CMS-70P，Zebris 社製）の Single Lumbar Mode を用いて調べた. 本機器はメジャー リング・センサーから発生する連続した超音波パルスを 体表に貼付した小型軽量のマイクロホンで受音すること によって，2 者間の距離の変化によるパルス到達時間の 変化を検出し, 三角測量によって三次元座標をサンプリ ングレート $60 \mathrm{~Hz}$ でリアルタイムに記録するシステムで ある. WINSPINEの Single Lumbar Modeの仕様にした がって, 第 2 腰椎棘突起から第 5 腰椎棘突起, 第 2 お よび第 3 仙椎, 左右上後腸骨棘の皮膚上にマイクロホン を設置し，4 分節を測定した（図 3 および4）。得られ

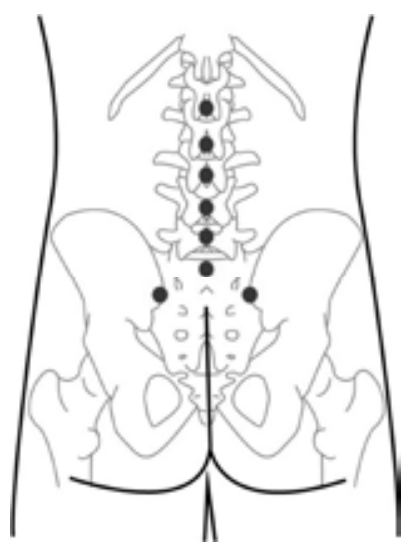

図3 マイクロホンの貼付部位

たデータから, 1 分ごとの 20 区間の平均值を算出して 比較検討に用いた。

統計的解析には StatView Ver.5.0 for windows を使用 した，有意水準は $5 \%$ に設定し，腰椎各分節の角度の開 始時に対する経時的変化を反復測定分散分析と多重比較 


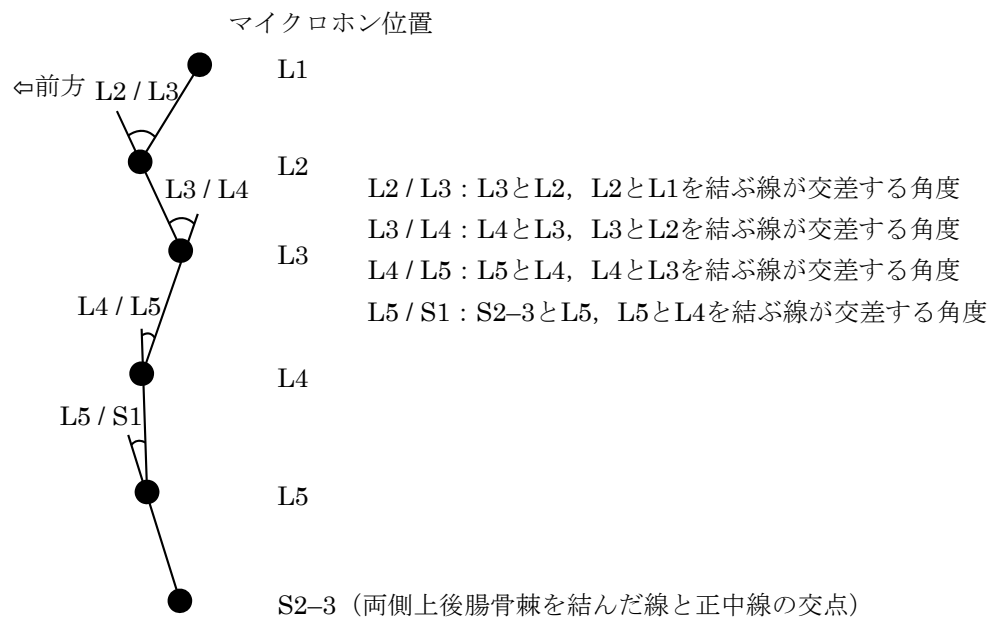

図4 マイクロホンの貼付部位

検定（Dunnett 法）を用いて有意性の検討を行った.

なお，全ての被検者には実験参加の前に，研究の目的， 課題内容などについて, 書面および口頭にて説明し, 同 意書に署名を得た。また，本研究の一連の手順は，星城 大学研究倫理専門員会の承認を受けた（承認番号： 2014C0004).

\section{III. 結 果}

各座位姿勢の腰椎の経時的な角度変化を表 2 に示す。 Lumbo-pelvic upright sittingにおいて, 腰椎全体の角度 変化は, 開始 4 分後から屈曲方向に有意な角度の増加を 示し, 各分節の角度変化の時期は, L2/3 間が 11 分後, L3/4 間が 7 分後, L4/5 間が 5 分後, L5/S1 間が 4 分後 から屈曲方向に有意な増加を示した. Slump sitting と Thoracic upright sittingは, 20 分間を通し腰椎全体と各 分節において有意な変化を示さなかった.

\section{IV. 考 察}

本研究は，長時間にわたる座位保持中の腰椎の角度を， 初めて分節ごとに観察することに取り組んだ研究であ る. その結果, Lumbo-pelvic upright sitting の腰椎全体 および各分節の角度変化は, 個人差は大きいもののほと んどの被験者に観察された。これは，脊柱を支持する主 な力源が, 筋から脊柱の䩲帯組織（棘間, 棘上鞀帯, 椎 間関節包など）や腰背腱膜などの受動性組織に徐々に移 行していると考えられ, 時間経過とともに負担度が増加 していくためと考えられる。ささらに，Slump sitting 時に 観察される角度に近づく程, 脊柱を支持する力源のほと んどをこの部位に依存することになる。また，有意な角 度増加が出現する時期が, 下位から順に上位へ移行して いたことから，下位の負担が大きいと考えられる。
Slump sitting は, 腰椎全体, 各分節の屈曲方向への角 度変化は観察されなかった。しかしながら，先行研究で は Slump sitting がFRP, クリープ現象を生じると報告 している ${ }^{15)}$. 開始直後から FRPのメカニズムにより, 受動性組織に負荷を依存していることが推測されるが, クリープ現象は生じなかったことが示唆された。この結 果は, 本研究で設定した座位保持時間と重量負荷が影響 していると考えられ，受動性組織に十分な負荷を与えら れなかった可能性がある。また，Adamsら 16)は，早朝 と午後で腰椎可動域を比較した時, 後者の方が 5。の増 加を示した。 これは, 椎間板の液体内容物の日内変動で あり, 負荷が加わると椎間板の水分含有量が減少し, 縦 径が減少するため受動性組織に緩みが出現したためと説 明している。 また, この現象は, 長時間の持続的な負荷 でも同様に生じると報告されており17), 本研究の測定 時間が 19 時以降であったため対象者にも同様の変化が 起きていた可能性もある.よって, 今回, Slump sitting により負担の集中する腰椎分節の位置は, 明らかになら なかったのではないかと考えられる。

Thoracic upright sittingは, 各分節の屈曲方向への角 度変化は観察されなかった。 O’Sullivanら13)は, Lumbo-pelvic upright sitting とは異なり表層筋が有意に 働いて座位保持をしていると報告している。よって，本 研究で設定した座位保持時間と重量負荷では屈曲方向へ の角度変化が観察されなかったのではないかと考えら れる。

現在の腰痛予防対策は，主に各腰部組織に過負荷を生 じないことを目的として，生理的前弯を保持する姿勢指 導や座面と背もたれの角度を調整するなどの環境整備が 推奨されている。しかしながら，本研究は，推奨される 座位の重要性を証明したと同時に，それを保持すること が困難であるという結果を示したため, 姿勢を頻繁に変 えることが効果的な対策であると思われる。 


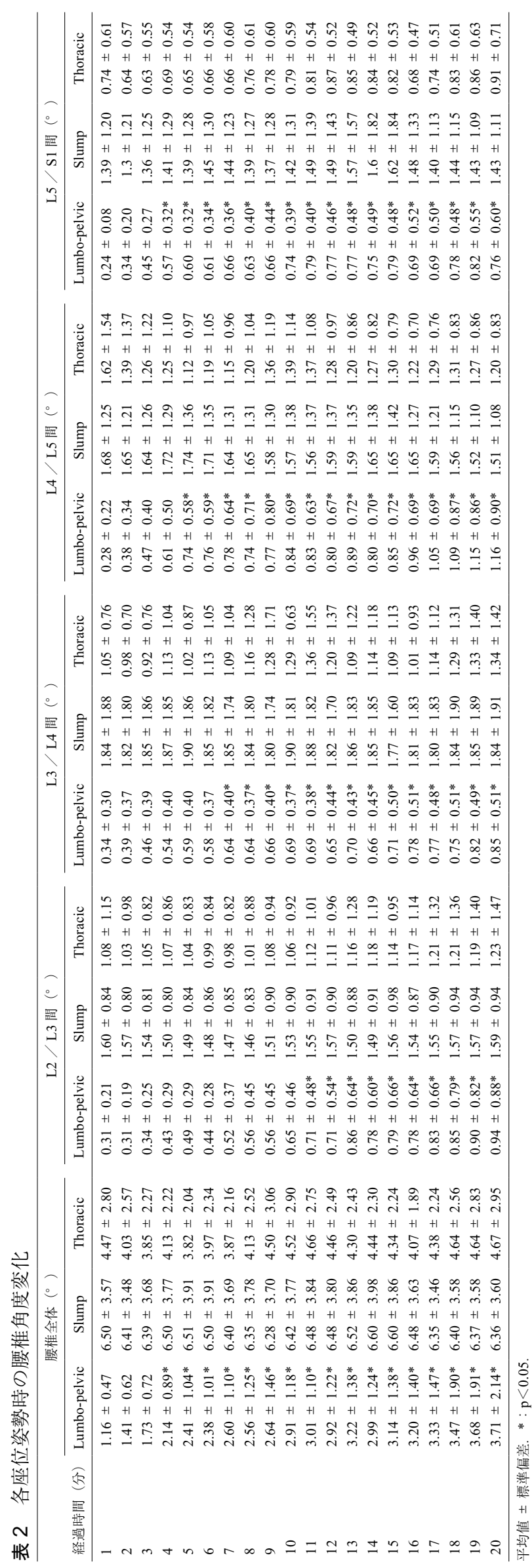

\section{引用文献}

1) 日本整形外科学会, 日本腰痛学会, 日本整形外科学会診療 ガイドライン委員会: 腰痛診療ガイドライン 2012. 南江堂, 東京, 2012, pp12-14.

2) Katz JN: Lumbar disc disorders and low-back pain: Socioeconomic factors and consequences. J Bone Joint Surg Am, 2006, 88: 21-24.

3) Cassidy JD, Carroll LJ, Côté P: The Saskatchewan health and back pain survey. The prevalence of low back pain and related disability in Saskatchewan adults. Spine, 1998, 23: 18601866, discussion 1867.

4) 厚生労働省：平成 25 年国民生活基礎調査. http://www. mhlw.go.jp/toukei/saikin/hw/k-tyosa/k-tyosa13/（閲覧日 2014 年7月 15 日).

5) Suka M, Yoshida K: The national burden of musculoskeletal pain in Japan: Projections to the year 2055. Clin J Pain, 2009, 25: 313-319.

6) 帖佐悦男, 田島直也, 松元征徳 - 他: 職業性腰痛の疫学. 日本腰痛学会誌, 2001, 7: 100-104.

7) Guo HR: Working hours spent on repeated activities and prevalence of back pain. Occup Environ Med, 2002, 59: 680688.

8) 厚生労働省 : 職場における腰痛予防対策指針の改訂及びそ の普及に関する検討会報告書. http://www.mhlw.go.jp/stf/ shingi/2r98520000034qql-att/2r98520000034qs0.pdf（閲覧日 2013 年 6 月 18 日).

9) Kelsey JL, White AA 3rd: Epidemiology and impact of lowback pain. Spine, 1980, 5: 133-142.

10) Williams MM, Hawley JA, McKenzie RA, et al.: A comparison of the effects of two sitting postures on back and referred pain. Spine, 1991, 16: 1185-1191.

11) Videman T, Nurminen M, Troup JD: 1990 Volvo Award in clinical sciences. Lumbar spinal pathology in cadaveric material in relation to history of back pain, occupation, and physical loading. Spine, 1990, 15: 728-740.

12) McGill SM, Brown S: Creep response of the lumbar spine to prolonged full flexion. Clin Biomech (Bristol, Avon), 1992, 7 : 43-46.

13) O'Sullivan PB, Dankaerts W, Burnett AF, et al.: Effect of different upright sitting postures on spinal-pelvic curvature and trunk muscle activation in a pain-free population. Spine, 2006, 31: E707-E712.

14) Kanlayanaphotporn R, Trott $P$, Williams M, et al.: Effects of chronic low back pain, age and gender on vertical spinal creep. Ergonomics, 2003, 46: 561-573.

15) Dolan P, Shandall S, Hodges K, et al.: 'Creep' in spinal tissues impairs spinal proprioception and delays activation of the back muscles. 51st Annual Meeting of the Orthopaedic Research Society, 2005, Washington, Paper No: 0275.

16) Adams MA, Dolan P, Hutton WC: Diurnal variations in the stresses on the lumbar spine. Spine, 1987, 12: 130-137.

17) Urban JP, McMullin JF: Swelling pressure of the lumbar intervertebral discs: Influence of age, spinal level, composition, and degeneration. Spine, 1988, 13: 179-187. 